\title{
Possible Aspects of Entrepreneurship in Space Tourism of the Future
}

\author{
Goran Kutnjak \\ Faculty of Economics, Rijeka, Croatia \\ Diana Blašković \\ Pharmacy “Ilona Lenac”, Labin, Croatia \\ Matija Radović \\ Faculty of Economics, Rijeka, Croatia
}

\begin{abstract}
Lately, an interest for space tourism in the world has been growing rapidly. It is a reflection of interest for tourist spending which strives for consumption of until now unrealized tourist experiences and destinations on one side, as well as implementation of a proactive politics of inventive entrepreneurship which has a desire to invest, and also makes an enormous profit off of space tourism on the other. Our current results of different studies around the world confirm a wide interest of tourist spending for this sort of selective tourism, so from that point of view, the first and main prerequisite is fulfilled. But, for space tourism to be accepted as a "mass movement", it is necessary to broadly adjust the prices of earlier, mainly individual arrangements, which mostly premiums lowering costs of manufacturing space shuttles, as well as their launch costs. In addition, it is necessary to systematically solve a whole bunch of open questions regarding legal, administrative, health, as well as, for example, insurance issues. In the spectrum of this field of research authors were trying to analytically, but still critically aspect the relevance of this, primarily futuristic industrial tourism "project”, and also interpret some of their visions of the given issue. Despite all the open speculations, it is undeniable that space tourism will have a future, that in the long term it will develop with the programmed fazes of development and that the expansion of space tourism will causally manifest onto all the segments of economic and social life.
\end{abstract}

Keywords: space, space tourism, space entrepreneur, space tourist

\section{Introduction}

Today, the tourism industry is for surely one of the most significant industries in the world, both in terms of number of employees engaged and its impact on the social and economic development of each country that sees tourism as a serious and potentially socially developmental and processing economic activity. Regardless the fact that tourism was already present in a large number of countries in the 19th century, it has become a phenomenon of large scale involving a great number of people since the second half of the 20th century. The

Goran Kutnjak, Associate Professor, Business administration Department, Faculty of Economics.

Diana Blašković, Ph.D. candidate, Business administration Department, Pharmacy “Ilona Lenac”.

Matija Radović, Assistant, Business administration Department, Faculty of Economics.

Correspondence concerning this article should be addressed to Goran Kutnjak, Faculty of Economics, Ivana Filipovića 4, 51000 Rijeka, Croatia. E-mail: goran.kutnjak@efri.hr. 
calculated data indicate that in the year 1950, only 10 out of 1,000 inhabitants of the planet Earth were involved in international tourism, whereas this number was nine times higher than that in 1993, i.e., 1994 (Stipetić, 1995, p. 105). In the mid-1990s of the last century, the tourism industry employed 212 million people, or every nine worker, and it accounted for $11 \%$ of world gross domestic product (Šubić, 1996, p. 18). It is expected that in this century, the tourism industry will continue to evolving rapidly, and the structure and number of employees engaged in tourism will change in accordance with the contents of the tourist offer, the standards of the population and its purchasing power, the development of new communication technologies, as well as the overall technological progress.

From a tertiary activity, the tourism industry will become a primary activity and today's primary activities will become its service. As far as people are concerned, the new century will be marked by more free time, increased living standards and higher quality of life. Namely, the man-employee will have more time for rest and leisure activities. These activities will be related to meet the distinct needs of all people for resting, preserving and fostering health, prolonging life, creating a state of comfort, pleasure and relaxation which will result in the increase of the life quality. To live a life of high quality means to live well, actively, healthy, free, at one's choice. Improving the quality of life is a great challenge of the tourism of the future (Avelini Holjevac, 2001, p. 11). This is how Pizam (1999, p. 339) sees the future, even though he is aware of the fact that forecasting is risky. The same author believes that by 2050 the tourism industry will become the largest industry of the world with two billion tourists and a revenue of 24 trillion U.S. dollars (domestic and foreign tourists), and that the major tourist destination will include India, China, Indonesia, and Brazil... According to the World Tourism Organization, the qualitative determinants of the future global tourism development forecast that the number of tourists will increase from 673 million in 2000 to a billion in 2010 and 1.6 billion in 2020 (Avelini Holjevac, 2001, p. 12).

Certain estimates by the UNWTO (World Tourism Organization, 1997) also suggested that tourism will continue to remain the leading industry, i.e., the most important primary activity, which can be seen in Table 1.

Table 1

Forecasts for Tourist Movement in the World and Regions (in Millions)

\begin{tabular}{|c|c|c|c|c|c|c|c|}
\hline \multirow{2}{*}{ Region } & \multirow{2}{*}{$\begin{array}{l}\text { Base year } \\
1995\end{array}$} & \multicolumn{3}{|c|}{ Forecasts } & \multicolumn{3}{|c|}{ Average annual growth rate (\%) } \\
\hline & & 2000 & 2010 & 2020 & $1995-2000$ & $2000-2010$ & $2010-2020$ \\
\hline Africa & 20 & 26 & 46 & 75 & 5.4 & 5.7 & 5.1 \\
\hline America & 110 & 131 & 195 & 284 & 3.6 & 4.0 & 3.8 \\
\hline East Asia/Pacific & 81 & 105 & 231 & 438 & 5.2 & 8.2 & 6.8 \\
\hline Europe & 334 & 386 & 526 & 717 & 3.0 & 3.2 & 3.1 \\
\hline Middle East & 14 & 19 & 37 & 69 & 6.4 & 7.1 & 6.5 \\
\hline South Asia & 4 & 6 & 11 & 19 & 5.6 & 6.8 & 5.8 \\
\hline World & 563 & 673 & 1,000 & 1,600 & 3.6 & 4.5 & 4.4 \\
\hline
\end{tabular}

As far as transportation goes, Pizam forecasts that by 2050, new means and possibilities of transportation will be possible, such as mega cruisers for five to 10 thousand passengers that will serve as floating resorts and centers of entertainment located in the open sea with passengers boarding and disembarking them offshore (Pizam, 1999, p. 340).

\section{Evolution of “Classical” Forms of Tourism Towards Space Tourism}

Since the emergence of tourism and during its historical periods, it is possible to distinguish among the 
following: (1) the period of privileged groups and individual tourism; (2) the period of mass tourism; and (3) the period of selective tourism. Mass tourism is still the prevailing and the most dominant category of tourism, also referred to as traditional, industrial, uniform, and "large” tourism. On today's development stage, mass tourism is considered to be that, which is available to all categories of tourist residents and is mainly seasonally motivated, i.e., by the "sun and sea" and/or "winter-mountain" activities. The growth and development of mass tourism began in the 1950s when the tourist masses were strongly concentrated in terms of time and space. In the past 40 years, mass tourism (large and ready-made) has been showing significant signs of crises, since the strong expansion of tourism onto the developed and some receptive countries has, in addition to many positive effects, had a series of negative consequences (Jadrešić, 1993, p. 167).

By abandoning the concept of mass tourism, a responsible development, based on selected programs and forms of tourism, is being supported. This development leads to a new diversification and quality on the ever more demanding tourist market resulting in the restructuring of tourism towards a balanced and polycentric development. Quantity and growth are being replaced by the development of the quality factors, i.e., the quality of choice, identity, environment, and ecology reducing the importance of mass tourism which is being transformed, in accordance with its potentials, into new forms or is being replaced by the new forms and types of tourism called selective tourism, or in other words the tourism of sustainable, supportable and reasonable management (Jadrešić, 2010, p. 171). In theory, this kind of tourism is referred to as: sustainable, responsible, high quality, environmentally friendly, alternative, specific, universal, individual, humanistic, tall, fit, genuine, elite, etc. tourism. Today, the most representative forms of selective tourism include: nautical, family, continental, health, rural, insular, mountainous, urban, cultural, religious, day-trip, recreational, sports, extreme, diving, hunting, fishing and etc. tourism, etc., and from recently space tourism.

The development of technology and the ingenuity of the human mind, made once an impossible idea of space travel for the common man, a reality. On April 29, 2001, the International Space Station (ISS) welcomed the first space tourist, Dennis Tito, a Californian millionaire and entrepreneur engaged in investment management, whose tourist venture had cost him USD 20 million and six months of rigorous preparation (Jurman, 2004, p. 1). He flew with Russian astronauts in a Russian spacecraft, ISS which is the official name of the space shuttle. In 2002, Mark Shuttleworth, a private entrepreneur, a great admirer of technology and space flight, was the second space tourist sent into space. The third space tourist flight was in 2005, by Gregory Olsen, a scientist involved in optical electronics. Mrs. Anousheh Ansari, a native of Iran, was the first female space tourist in the 2006 (She and her family also support the spaceport in Singapore). The co-founder of Microsoft Office and the owner of the International Software, Charles Simonyi flew into space in 2007 (Burić \& Bojkić, 2007, p. 7). It is still not known how much money they have spent on individually but the value of individual flights is estimated to about USD 20 to 30 million. There are some forecasts that say that if we take in mind the further development of technology, the prices of flights will fall down to USD 30,000 after 2010 (Klauški, 2008, pp. 2-3). However, there is no doubt that these commercial space flights, have brought about the development of the complete tertiary sector of the industry named space tourism.

\section{Development and Commercialization Perspectives of the Space Industry}

So far, the Western governments have invested several hundreds of billion dollars into the space industry. However, in order for the space industry to experience a real boom and realize its potential, it is necessary to commercialize it, i.e., to allow commercial capital investments and abolish state monopoly. Dozens of 
companies are eager to get into a position that could, according to estimates, "weigh" billions of dollars. Moreover, in professional tourism literature, there are theoreticians, who have in their works, analyzed and introduced new expressions in the tourism terminology explaining the term "space tourist". For example, the term "space tourist market" encompasses all individuals who express a desire or intention to travel, as tourists, to space.

The results of one of the first research on space tourism, conducted on a sample of 1,500 respondents from American families were published as early as 1996. In this research, 34\% of respondents reported an interest in spending two weeks in a spaceship, and even $42 \%$ of respondents wanted to cruise around the universe, which would be an equivalent to today's sea cruises. Particularly indicative was the fact that the majority of respondents expressed their intention to spend USD 100,000 or more on such a journey. Similar results in the interest of potential tourists for tourist trips were reached by a survey carried out in Japan in the late 20th century involving a sample of more than 3,000 respondents. The survey found that more than $45 \%$ of people over 60 firmly stated that they were very much interested in various forms of space travel, but showed the most interest in journeys lasting for several days. Even $20 \%$ of respondents claimed that they were ready to spend their entire annual income on such an experience. Similar results were achieved by surveys conducted in other countries, such as the one conducted Germany in 1996 or the one in 1999 in the UK (Vukonić, 2010, p. 199). Above all, recent research conducted in the United States show that in 2005, approximately 20 million Americans were ready to board a spacecraft, and engaged uncertainty, naturally, if the price was lower. This figure falls dramatically as the travel expenses increase, but even at the price of USD 100,000 the predictions are that the market would include almost half a million of people.

As early as 1985, when a survey was carried out on a sample of 1,000 respondents in the USA asking whether they would like to spend their holidays in space, $50 \%$ of the respondents answered affirmatively even though the price of such a journey was unquoted.

Therefore, even then, the idea of such type of vacation was considered interesting and challenging to many. Based on the research carried out by Society Expeditions Inc. from Seattle, assessing the market interest for space tourism services, the following data were gathered in Table 2 (Lončar, 2005, p. 4).

Table 2

\section{Prices and the Number of Passengers Interested in Space Tourism}

\begin{tabular}{ll}
\hline Price (in USD) & Number of passengers on annual basis \\
\hline $1,000,000$ & 50 \\
500,000 & 100 \\
100,000 & $500-1,000$ \\
50,000 & 5,000 \\
25,000 & $30,000-40,000$ \\
\hline
\end{tabular}

On the other hand, there are also some interesting predictions in Futron's studies on the development of space tourism. Futron offered objective viewpoints on the future of this industry, and he predicts that by 2021 the space tourism industries could generate about a billion dollars a year, with more than 15,000 people reaching the space boundary, i.e., will have seen the Earth from a perspective that is now possible only to some (Burić \& Bojkić, 2007, p. 2). The mentioned study also states that more than 15,000 passengers will participate in suborbital space flights generating thus USD 700 million, and even 60 passengers in orbital flights (compared to the present number of 1-2 passengers per year) bringing USD 300 million. 
There are several phases needed to completely commercialize space tourism and vacations on orbit stations, or the moon, among which, the first two have already been performed, although by planes to be fair (Jurman, 2004, p. 2).

(1) The first phase involves weightlessness (or parabolic) flights, which are being performed on the Russian flying fortress (aircraft), the IL-76. However, such flights are also performed by cargo planes such as Boeing 727-200 used by the Zero Gravity Corporation, whereas, the French Novespace uses Airbus A-300. The simulation of weightlessness is done in a way that the aircraft climbs to a height of 9-10 kilometers after which it plunges to six kilometers. The curve which is then performed neutralizes gravity and the plane remains floating in air for about 25 seconds. This procedure is conducted ten times or for four minutes of zero gravity in total. ZeroG, a company with an indicative name, offers this experience to all interested. They are among the companies offering the cheapest and most massive commercial flights. ZeroG has estimated the value of such flights to USD 3,500 per person, while the Russian company Rustourism values it at USD 2,500 per person;

(2) The second phase includes suborbital flights-those reaching up to $100 \mathrm{~km}$ of altitude and include the return to the Earth. Namely, the $100 \mathrm{~km}$ boundary, called the Kormarov line, was determined by the International Astronautical Federation, and represents a rough administrative boundary between the Earth's atmosphere and outer space. At this altitude, the air resistance is too small and a couple of orbits would slow down the spacecraft enough to "fall” out of orbit. The suborbital flight lasts for approximately 2.5 to 3 hours whereas the state of weightlessness for only 3-5 minutes. The mere preparations for such a flight last for about 5 days, during which the space tourist is being trained for all possible situations that might occur during the flight. Suborbital flights are cheaper in relation to those orbital. Namely, a suborbital flight offered by Viorgin Galactic costs around USD 200,000 (Jurman, 2004, p. 5). According to the difference in the price, it can be concluded that these two types of flights do not provide an anywhere similar experience, although they are both very attractive. This type of flights is being performed in Russia on MiG 29s;

(3) The third phase involves orbital flights - those that reach and retain in the Earth's orbit. So far, they have been performed five times and each time successfully. They are performed once or twice a year because there is yet no other place in space, except the International Space Station, to which the spacecraft could attach itself to. Furthermore, the reasons for such rare orbital travel lie in the fact that the space travelers are allowed to travel only during the International Space Station crew shift which last for about 10 days. The space traveler then goes with the crew, as an additional member, and returns with the crew going home. During the entire 10 days, the space traveler spends in weightlessness alongside the professional astronauts. This phase, which is the most important, insists on the design and construction of a spacecraft, the "Reusable Launch Vehicle" (RLV), which will be cheaper to launch than the launching of a "shuttle". The price of a "shuttle" flight is USD 20,000 per kilogram of weight. In order to reach the stage of orbital flights commercialization, this price should be lowered to at least USD 5,000 per kilogram. Moreover, cheaper spacecrafts lead to lighter constructions of orbital stations, thus opening the door for a fourth stage;

(4) The fourth phase includes accommodation at the space station-during the orbital space flight the spacecraft joins the International Space Station. The development of such flights will cause problems in their attachment to the International Space Station.

Considering the fact that in the future, there will be an increased number of orbital flights, the International Space Station will not have the capacities to receive all spacecrafts. Although this problem has not occurred yet, the company Bigelow Aerospace has been working on a station which would be sent into space to 
receive spacecrafts during their orbital flights (Burić \& Bojkić, 2007, p. 11);

(5) The fifth phase includes hotels and space habitats (either in orbit or on the moon). Japanese construction giant Shimuzu announced that in 2020, it plans to open an orbital hotel with 60 rooms at the altitude of $450 \mathrm{~km}$ above the Earth. Moreover, during the 60th, O’Neall and his colleagues designed a project entitled "space settlement”, i.e., habitat. The problem of a hundred year-lag length to build such a habitat makes them seem very distant and unachievable at the moment. Some visionaries talk about the sixth stage-space culture and sports (e.g. orbital galleries or stadiums).

Above all, some companies have already started with space business. SpaceShipOne, the first private manned spacecraft was launched on June 21, 2004 from the Mojave Desert. This spacecraft, designed in Scaled Composits, is the leader in the development of orbital tourist flights. However, although it has an imposing name, the spacecraft has been designed only for ballistic flight and is not intended to enter into orbit. In addition, the company space adventures that wishes to develop space tourism is already recording bookings and confirmations for orbital flights at a cost of USD 20 million per person. There are also those interested in flights around the moon but in order to do so, one must be willing to spend a sum of USD 100 million (Lončar, 2005, p. 1).

\section{Current Issues Related to Space Tourism and Solution Factors}

In the distant future, once the drastic fall in the cost of orbital flights occurs (price below USD 100,000 per passenger) and when the individual demand for recreational trips into space suddenly increases, there will be a true development of space tourism. Truthfully, there are still a number of issues to be addressed systematically in order to reduce to a minimum certain risks and open questions. Among other things, these issues relate to the following (Vukonić, 2010, p. 200):

(1) Spacecrafts should be modulated in order to be able to return to earth and then be re-launched for the same purpose in a relatively short time. This could reduce the cost of production and launch by nearly $90 \%$;

(2) In order to decrease production and launch costs by $90 \%$, besides a suitable aircraft, the number of passengers, i.e., launch (space) traffic should also increase. In order for this to happen, the service providers should offer lower prices and thus attract potential passengers;

(3) The technology required for all activities in the Earth's orbit is very sophisticated and very expensive;

(4) The safety of passengers depends on the level of internal equipment and comfort offered by the spacecraft intended for tourist trips;

(5) It is also necessary to complete very comprehensive and sensitive administrative and legal jobs prior to the introduction of more space tourist flights. In this regard, the work is just beginning, although several international meetings, congresses and symposia discussing these issues have already been held;

(6) Space flight experts are particularly suspicious in terms of health care legislation that will have to follow the development of space tourism. Namely, experience has shown that the astronauts' health status, despite the thorough preparation before the flight, often deteriorated. The question is how tourists will behave during spacecraft acceleration and vibrations, in conditions of weightlessness, as well as the issue of radioactive impact on individuals;

(7) It is also necessary to see who and under what circumstances will bear the health insurance of tourists during their travel through space;

(8) What effect will tourist traffic to space have on different space research, satellite programs, etc., and vice versa; 
(9) Will, in just ten years as some predict, mankind succeed in finding solutions to the basic problems without which it will be difficult to consider commercializing tourist trips into space?

In addition to the above questions, there is a whole range of questions among which are: How and who will be in charge of controlling commercial tourist space flights? How will space tourism be regulated at international level? What are the responsibilities of the departure countries? Who will be responsible during the time of flight or the time spent at the space station and who will cover the costs? Who will bear the risk of danger for passengers? How will necessary rescues if needed be regulated? The fact is that similar issues occurred in other tourism areas (periods) as well. However, after decades of intense organization of tourist trips by tour operators, all these were resolved (some immediately, some "as one goes"). Practice had given people very specific answers, and thus these issues are no longer raised. Consequently, regarding these issues, the solutions for the initial problems will be found relatively quickly, especially when tourist space travel becomes an established practice.

These, as well as many other questions, are primarily addressed by the competent world institutions such as NASA and ESA, around which many world countries as well as EU member states are integrated.

Already in 1997, NASA published a report with forecasts on the possibility and profitability of space tourism. Although it was a small report, the forecasts were more than good, and the predictions talked about billions of dollars on annual basis. The meticulous Japanese made their own, more extensive, survey which reached even better results. The figures talked about space tourism as an industry that will, in its first decade, generate a profit of 10 billion dollars per year which will be doubled during the next decade. However, in order for this industry to be launched, the main problem of the commercialization of space tourism has to be resolved, and this is the price of launching the spacecraft into space. In 1998, NASA and the Space Transportation Association conducted a new study stating that, with the advances in technology, the price of space travel arrangement should cost 50,000 U.S. dollars and attract half a million tourists in 2010. Using math basics, one comes to 25 billion dollars in profits from space tourism per year for the period 2010-2020 (Jurman, 2004, p. 2). Even if we looking optimistically, we still have to say that these forecasts are a bit exaggerated and that at least another, 10 years will go by before the beginning of the era of space tourism, and the cited figures could maybe be achieved by the end of this decade.

The European door to space is the ESA (European Space Agency). Its goal is to develop European space capacities and to ensure a continuity of investments into research. Its task is to draft a European space program, as well as its future implementation. ESA projects are designed to find out more about the earth, the solar system and universe, but also to develop space technologies and services and promote the European industry. ESA cooperates with space organizations outside Europe, and has 17 member states: Austria, Belgium, Denmark, Finland, France, Germany, Greece, Ireland, Italy, Luxembourg, the Netherlands, Norway, Portugal, Spain, Sweden, Switzerland, and the United Kingdom. As it can be noticed, not all ESA members are EU member states. ESA is a completely separate organization, although it is tightly connected to the EU. ESA headquarters are in Paris, but there are also other centers in Europe (the Netherlands, Germany, Italy, and Belgium) and even in the United States and Russia, each being in charge for different responsibilities. ESA employs approximately 1,900 people with a budget of 2,977 million euros and receives funds from member states (Lončar, 2005, pp. 4-5).

It is very important to understand the size of today's space industry, its future development trends and the impact of these trends on national and world economy and other industries. The development of space industry 
could open up many jobs, and also impact the change in the employment structure. This development requires an increase on the labor market in number of engineers, technicians, mechanics, and scientists. These flows might be even joined by the developing countries, because there will be a significant market expansion and the circumstances are now such that they require mutual co-operation between civil, military and commercial users of space. China is a good example of a country joining space flows, with over 460 institutions and organizations employing 10,000 engineers and technicians who are directly involved in applied research, testing and manufacture of satellites. In cooperation with Japan, China is also intensely engaged in micro gravitational research, and it also cooperates with Russia. Certainly, the Chinese biggest achievement was launching mankind into space in 2003, by which China became the third country in the world to launch a manned spacecraft (Lončar, 2005, p. 4).

\section{Conclusion}

Space tourism will surely be getting even more publicity, marketing and wider recognition over some shorter period of time, as well as more specific market significance within the tourist valorization of individual segments of selective types of tourism. Unquestionably, space tourism is already realizing some of its goals-individual flights (travel) have already been performed and space tourism consumption is being more and more aggressively agitated and aggregated through bookings. However, in order for individual countries to have a space industry with actual space enterprise, it is necessary to meet the first prerequisite-the commercialization of space travel. Among all, this primarily implies a drastic drop in space technology production and launch costs, the involvement of the private sector, a closer approach to the "small" people, establishment of certain legal and administrative as well as health-insurance and other regulations and ultimately, the development of space tourism. However, there is no doubt that the issue of space tourism, in the true sense of the word, is entering through the "main gate" and that it, in its basis, has already a wide mass of supporters infected by the "alien" consumer mentality.

\section{References}

Avelini Holjevac, I. (2001). Budućnost turizma—-trendovi i izazovi. Suvremeni promet. Hrvatsko znanstveno društvo za promet. $1-2,11-15$.

Burić, T., \& Bojkić, L. (2007). Studija izvedivosti svemirskog turizma u Hrvatskoj. Retrieved from http://www.spaceforum.org/files/ Svemirski_turizam_studija.pdf

Jadrešić, V. (1993). Nove tendencije i orijentacije u turizmu. Turizam 7-8, 166-173.

Jadrešić, V. (2010). Janusovo lice turizma. Od masovnog do selektivno-održivog turizma. Zagreb: Plejada Jurman, D. (2004). Svemirski turizam. Odmor među zvijezdama. Retrieved from http://www.djurman.com/best/space/spaceturizam. htm

Klauški, T. (2007). Svemirski turizam: 2008. godine u orbiti za samo 200.000 dolara. Retrieved from http:// www.poslovni.hr/vijsti/svemirski-turizam-2008-godine-u-orbiti-za-samo-200000-dolara-40375.aspx

Lončar, J. (2005). Industrija $i \quad$ turizam $u$ svemiru? Retrieved from http://www.geografija.hr/clanci/printverzija/775/industrija-i-turizam-u-svemiru.htm

Pizam, A. (1999). Life and tourism in the Year 2050. International Journal of Hospitality Management, 18(4), 331-343.

Stipetić, V. (1995). Nove tendencije u svjetskom turizmu. Računovodstvo, revizija i financije, 5, 103-116.

Šubić, N. (1996). Turizam-ključ hrvatskog gospodarstva. Hrvatski turistički magazine, 2, 15-21.

Vukonić, B. (2010). Turizam. Budućnost mnogih iluzija. Zagreb: Visoka poslovna škola Utilus \& Plejada.

World Tourism Organization. (1997). Seminar on Tourism Statistics and Economic Impact Measurement. Cairo: World Tourism Organization. 